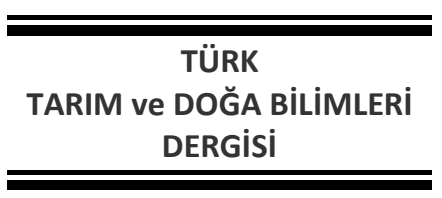

\title{
Ekmek İsraf Etme Durumunun ve İsrafta Etkili Olan Faktörlerin Belirlenmesi: Kahramanmaraş Kent Merkezi Örneği
}

\author{
Emine IKIKAT TÜMER ${ }^{1}$, Yeşim AYTOP ${ }^{2 *}$, Kubilay Burak YAVUZ ${ }^{1}$ \\ ${ }^{1}$ Kahramanmaraş Sütçü İmam Üniversitesi, Ziraat Fakültesi, Tarım Ekonomisi Bölümü, Onikişubat/Kahramanmaraş \\ ${ }^{2}$ Kahramanmaraş Sütçü İmam Üniversitesi, Pazarcık MYO, Dış Ticaret Bölümü, Pazarcık/Kahramanmaraş \\ *Sorumlu yazar e-mail: yesimmeral@ksu.edu.tr
}

Geliş Tarihi: 20.03.2019

Düzeltme Geliş Tarihi: 25.06.2019

Kabul Tarihi: 27.06.2019

Özet

Bu araştırmanın amacı Kahramanmaraş ili kent merkezindeki tüketicilerin ekmek tüketim durumlarını ve ekmek israfına etki eden faktörleri belirlemektir. Araştırmanın ana materyalini Kahramanmaraş ili kent merkezinde 384 tüketici ile yapılan anketlerden elde edilen veriler oluşturmaktadır. Verilerin analizinde tanımlayıcı istatistikler, One-Way ANOVA ve Ki-kare testlerinden yararlanılmıştır. Araştırma bulgularına göre, hanehalklarının günde ortalama 3.18 adet ekmek tükettikleri ve bu ekmeğe 3.24 TL/gün harcadıkları tespit edilmiştir. Tüketiciler en çok somun ekmeği tercih etmektedirler. Tüketicilerin \%55.99'u ekmek israfında bulunmakta ve günlük alınan ekmeğin \%9.17'sini israf etmektedirler. Araştırma sonucunda, ekmek israf etme durumu ile eşin çalışması, oturdukları binada kapıcı olma durumu, hanehalkı birey sayısı, gelir, kilo problemi olma durumu ve ekmek satın alma sıklığı arasında istatistiki açıdan anlamlı bir farkın olduğu tespit edilmiştir. Bu sonuçlar değerlendirildiğinde ekmeği sıklıkla satın alan ve taze olarak tüketen tüketicilerin ekmek israfını önlemek amacıyla ekmeğin gramajının azaltılması önerilmektedir. Geliri yüksek ve eşi çalışmayan tüketicilere, artan ekmekleri değerlendirmeleri yöntemlerini içeren seminerlerin verilmesi ekmek israfını azaltmaya katkı sağlayacaktır.

Anahtar kelimeler: Ekmek israfı, tüketim, Kahramanmaraş.

\section{Determination of Bread Waste Condition and Factors Affecting Waste: The Case of Kahramanmaraş City Center}

\begin{abstract}
The objective of this study is to determine the bread consumption status and the factors affecting the bread waste of the consumers in the city center of Kahramanmaraş. The main material of the study is the data obtained from the surveys conducted with 384 consumers in the city center of Kahramanmaraş province. Descriptive statistics, One-Way ANOVA and Chi-square test were used to analyze the data. According to the findings of the research, it was found that households consumed on average 3.18 pieces of bread in a day and they spent 3.24 Turkish Liras/ day on bread. The majority of the consumers prefer consuming the loaf of bread. The percentage of the consumers wasting bread is around $55.99 \%$, and $9.17 \%$ of bread bought by the consumers is wasted. According to the results of the research, it was found that there was a statistically significant relationship between bread wasting status and when spouse's work, the state of being a janitor, the number of people in households, income, the state of having a weight problem and bread purchase frequency. The results of this study will provide a source for the studies to be done by producers, consumers, and policymakers. When these results are evaluated, it is recommended to reduce the weight of bread to avoid wasting bread for consumers who frequently buy and
\end{abstract}


consume fresh bread. Giving seminars to high-income and non-working consumers on methods of evaluating increased bread will contribute to reducing bread waste.

Keywords: Bread waste, consumption, Kahramanmaraş.

\section{Giriş}

Insanoğlunun en temel ihtiyaçlarından biri olan beslenme; "bireyin mevcut sağlığı ve yaşam kalitesinin sürdürülebilirliğini sağlamak, beden gelişimini tamamlamak için ihtiyacı olan besin öğelerinin, yeterli ve dengeli miktarlarda, uygun zamanlarda almak için bilinçli yapılması gereken bir eylem" olarak tanımlanmaktadır (Anonim 2019a). Yerleşik hayata geçilmeden avlanarak beslenen insanların, yerleşik hayata geçiş ile birlikte tükettikleri besinler çeşitlenmiştir. Bu çeşitlerin en önemlisi 9 bin yıl önce üretilen buğdaydan (Anonim 2019b) yaklaşık 8 bin yıl önce yapılan ekmektir (Anonim 2019c).

Her öğün sofralarda yer alan ekmek, sanayi devrimi ile birlikte yerini simit, poğaça, çörek, börek, pilav, makarna gibi yiyeceklere bırakmıştır. Ekmeğin yerini alan bu yiyeceklerin ve öğünlerdeki yemek çeşitlerinin çokluğu ekmek tüketiminin azalmasına neden olmuştur. Dünyada kişi başına ekmek tüketimi en fazla olan Türkiye'yi ( $284 \mathrm{gr}$ ), Almanya ( $246 \mathrm{gr}$ ) ve Rusya (219 gr) takip etmektedir (TMO, 2013). Türkiye'de 1974 yılında kişi başı günlük ekmek tüketimi $401 \mathrm{gr}$ iken bu rakam 1984 yılında 360 gr'a ve 2006 yılında 199 gr'a düşmüştür (Boyacıoğlu, 2019). Toprak Mahsulleri Ofisi (TMO) 2013 yılı Türkiye'de Ekmek İsrafı Raporu'na (TMO, 2013) göre kişi başı ekmek tüketimi 2012 yılında 319 gr, 2013 yılında ise 284 gr olarak belirtilmiştir. Standart 250 gramlık ekmek üzerinden değerlendirildiğinde 2013 yılında kişi başı ekmek tüketim miktarı 1.14 adet olarak tespit edilmiştir. Son yıllarda tüketici tercihlerinin değişmesi ile birlikte ekmek tüketimi azalmasına rağmen ekmek israfında artış olmuştur. Taze ve sıcak ekmek tüketim isteği, ekmek tüketim ve israfını artıran tüketici tercihleri arasında en önemli unsurlardır. Alınan ekmeğin israf edilme nedenleri arasında ise uygun şartlarda muhafaza edilmemesi, dilimlenmeden sunulması, gramajın fazla olması, ekmeğin ömrünün kısa olması, çabuk bayatlaması, bayatlamış ekmeğin değerlendirilmemesi, fiyatının ucuz olması nedeniyle hanehalkı bütçesinde önemli bir paya sahip olmaması, intiyaçtan fazla ekmek alınması sayılabilir (Gül ve ark., 2003; Aydın ve Yıldız, 2011; Ekmekçi ve ark., 2013; Ertürk ve ark., 2015; Çağrı, 2016; TMO, 2013; Boyacıoğlu 2019).

TMO tarafindan 2012 yilında yapılan araştırmaya göre Türkiye'de 101 milyon adet ekmek üretilmekte ve bunun 95 milyonu tüketilmektedir.
Diğer bir ifadeyle günde 6 milyon ekmek israf edilmektedir. Ülkede 2008 yılında \%5 olan israf oranı 2012 yılında \%5.94'e yükselmiştir. Bu yükseliş karşısında TMO kampanyalar düzenlenmiş ve 2013 yılında üretilen ekmek 90.9 milyon adet, tüketilen 86 milyon adet, israf edilen ise 4.8 milyon adete düşmüştür. Yıllık ekmek israfının parasal karşılı̆̆ı 2012 yılında 1.6 milyon TL iken 2013 yılında 1.3 milyon TL olmuştur. 2012-2013 yılları arasında ekmek israf oranı \% 0.5 azalırken ülkenin kazancı ise 300 bin TL olmuştur. 2018 yılı gıda israf raporuna göre tüketiciler ekmeğin \%11.7'sini çöpe atma eğiliminde olduğu tespit edilmiştir (Anonim, 2019d; 2019e).

Dünyada ekmek tüketicilerinin profilinin ortaya konulduğu (Açan, 2007; Demir ve Kartal, 2012), tüketici tutumları (Cop ve Doğan, 2009) ve tercihlerinin (Aydın ve Yıldız, 2011; Koç, 2011; Aljobair, 2017) belirlendiği, ekmek israfının ortay konulduğu (Gül ve ark., 2003; Mohammmadi, 2006; Bal ve ark., 2013; Dölekoğlu ve ark., 2014; Ertürk ve ark., 2015; Capone ve ark., 2016; Aljobair, 2017; Taş̧ı ve ark., 2017; Demirtaş ve ark., 2018) bir çok çalışma yapılmışır.

Kahramanmaraş ilinde ekmek tüketim ve israfı ile ilgili çalışmanın yapılmamış olması çalışmanın önemini bir kat daha artırmaktadır.

Bu araştırmanın amacı Kahramanmaraş ili kent merkezindeki tüketicilerin ekmek tüketim durumlarını ve ekmek israfına etki eden faktörleri belirlemektir.

Ekmek israfı konusunda yapılan çalışmalar üretici ve tüketicilerin bu konuya duyarlılı̆ını artıracak ve ekmek israfının, dolayısıyla israftan kaynaklanan ekonomik kayıpların azalmasını sağlayacaktır.

\section{Materyal ve Yöntem}

Araştırmanın ana materyalini 2016 yılında Kahramanmaraş kent merkezindeki tüketicilerle yüz yüze yapılan anketlerden elde edilen veriler oluşturmaktadır. Çalışmanın ikincil verilerini ise konu ile ilgili yerli ve yabancı kaynaklar oluşturmaktadır. Anket yapılacak kişi sayısı Oransal Örnekleme Yöntemi ile tespit edilmiş (Newbold, 1995) ve \%90 güven aralığı $\% 5$ hata payı ile örnek hacmi 384 olarak bulunmuştur.

$$
n=\frac{N p(1-p)}{(N-1) \sigma_{\hat{p}_{x}}^{2}+p(1-p)}
$$


Formülde; n:Örnek büyüklüğü, $\quad \mathrm{N}$ : Popülâsyondaki birey sayısı (1089038), p: İncelenen olayın meydana gelme olasılığını (0.5), $\sigma_{p_{x}}^{2}$ : Oranın Varyansı, r: ortalamadan izin verilen hata payı (\%5), değeri, ifade etmektedir.

Verilerin analizinde tanımlayıcı istatistikler, One-Way ANOVA Testi ve Ki-kare testlerinden yararlanılmıştır. Gelir grupları ile ekmek tüketim miktarı, ekmek harcaması, gıda harcaması ve ekmek harcamasının gıda harcaması içindeki payı arasındaki istatistiki farkı belirlemek amacıyla One-way ANOVA testinden, ekmek israf etme durumu ile sosyodemografik özellikler arasında karşılaştırma yapmak amacıyla ki-kare testinden yararlanılmıştır.

\section{Bulgular ve Tartışma}

Anket yapılan tüketicilere ait demografik özellikler Çizelge 1'de verilmiştir. Çizelge 1 incelendiğinde tüketicilerin $\% 48.2^{\prime} \operatorname{sinin} 30-45$ yaş arasında (ortalama yaş: 38.09 yıl), \%57.8'inin erkek, \%73.4'ünün evli, \%23.8'inin özel sektör çalışanı, \%19.4'ünün emekli olduğu tespit edilmiştir. Bunun yanı sıra tüketicilerin $\% 50.5^{\prime}$ inin hanehalkı ortalama aylık gelirlerinin 2000-3999 TL arasında olduğu (hanehalkı ortalama aylık gelir: $2858.13 \mathrm{TL}$ ) ve gıda harcamasına aylık ortalama 512.62 TL ayırdıkları tespit edilmiştir. Tüketicilerin \%52.1'inin 3-4 kişiden oluşan haneye (hanede yaşayan ortalama birey sayısı:3.75) ve ortalama 1.64 çocuğa sahip oldukları ve \%49.5'inin 9-12 yıl arasında eğitim aldığı belirlenmiştir.

Çizelge 1. Anket yapılan tüketicilerin sosyo-demografik özellikleri

\begin{tabular}{|c|c|c|c|c|c|}
\hline Demografik özellikler & Kişi sayısı & Oran (\%) & Demografik özellikler & Kişi sayısı & Oran (\%) \\
\hline Yaş (yıl) & & & \multicolumn{3}{|l|}{ Gelir (TL) } \\
\hline $19-29$ & 104 & 27.1 & 400-1999 & 114 & 29.7 \\
\hline $30-45$ & 185 & 48.2 & $2000-3999$ & 194 & 50.5 \\
\hline $46-70$ & 95 & 24.7 & $4000-20000$ & 76 & 19.8 \\
\hline Toplam & 384 & 100.0 & Toplam & 384 & 100.0 \\
\hline Cinsiyet & & & \multicolumn{3}{|l|}{ Hanehalkı sayısı } \\
\hline Kadın & 162 & 42.2 & $1-2$ & 84 & 21.9 \\
\hline Erkek & 222 & 57.8 & $3-4$ & 200 & 52.1 \\
\hline Toplam & 384 & 100.0 & $5-10$ & 100 & 26.0 \\
\hline Medeni durum & & & Toplam & 384 & 100.0 \\
\hline Bekar & 102 & 26.6 & \multicolumn{3}{|l|}{ Ailedeki çocuk sayısı } \\
\hline Evli & 282 & 73.4 & 0 & 105 & 27.3 \\
\hline Toplam & 384 & 100.0 & $1-2$ & 190 & 49.5 \\
\hline Meslek & & & $3-7$ & 89 & 23.2 \\
\hline Kamu çalışanı & 59 & 15.4 & Toplam & 384 & 100.0 \\
\hline Özel sektör çalışanı & 91 & 23.8 & \multicolumn{3}{|l|}{ Eğitim durumu (yıl) } \\
\hline Emekli & 74 & 19.4 & $0-5$ & 29 & 7.6 \\
\hline Serbest meslek & 48 & 12.5 & $6-8$ & 41 & 10.7 \\
\hline Ev hanımı & 68 & 17.7 & $9-12$ & 190 & 49.5 \\
\hline Diğer & 43 & 11.2 & $13-21$ & 124 & 32.3 \\
\hline Toplam & 384 & 100.0 & Toplam & 384 & 100.0 \\
\hline $\begin{array}{l}\text { Gelir grupları } \\
\text { ilişkin bilgiler Çizelge } \\
\text { ekmek miktarının orta } \\
\text { (kişi başı günlük ekme } \\
\text { ve ekmeğe ortalama } \\
\text { edilmiştir. Gelir arttıl } \\
\text { (p<0.05) ve ekmek } \\
\text { gözlemlenmektedir (Çiz } \\
\text { Türkiye İstatistik Kurun } \\
2003 \text { yılı verilerini ar } \\
\text { arttıkça ortalama ekm }\end{array}$ & $\begin{array}{l}\text { le ekmek } \\
\text { verilmiştir. } \\
3.18 \text { adet/g } \\
\text { im ortalama } \\
\text { /gün ödedi } \\
\text { mek tüketi } \\
\text { sının arttığ } \\
\text { Akbay ve } \\
\text { (TüiK) tem } \\
\text { lerek Türki) } \\
\text { etim mikta }\end{array}$ & $\begin{array}{l}\text { üketimine } \\
\text { olduğu } \\
212 \text { gr) } \\
\text { ri tespit } \\
\text { miktarı } \\
(p<0.01) \\
(2008) \\
\text { ettikleri } \\
\text { de gelir } \\
\text { In artığı }\end{array}$ & \multicolumn{3}{|c|}{$\begin{array}{l}\text { sonucuna ulaşmışlardır. Kahramanmaraş ilinde } \\
\text { yapılan bir diğer çalışmada ise ekmeğin gelir } \\
\text { esnekliğinin } 0.55 \text { olduğu diğer bir ifadeyle gelirin \%1 } \\
\text { artması durumunda ekmek tüketim miktarının \%0.55 } \\
\text { artacağı sonucuna ulaşılmıştır (Akbay, 2005). } \\
\text { Tüketiciler aylık ortalama } 512.62 \text { TL gıda harcaması } \\
\text { yapmaktadırlar. Yüksek gelir grubundaki üreticiler } \\
\text { gıda harcamasına } 796.71 \mathrm{TL} \text { ayırırlarken, düşük } \\
\text { gelirliler } 305.57 \mathrm{TL} \text { ayırmaktadırlar. Aylık ekmek } \\
\text { harcamasının gıda harcaması içerisindeki oranı } \\
\text { ortalama \%18.96'dir. Gelir arttıkça ekmek }\end{array}$} \\
\hline
\end{tabular}


harcamasının gıda harcamasındaki oranı giderek azalmaktadır $(p<0,01)$ (Çizelge 2). Kahramanmaraş ilinde yapılan başka bir çalışmada ekmek ve tahıl harcamasının toplam gıda harcaması içindeki payı \%23.71 (Akbay, 2005), Isparta ilinde ise ekmek harcamasının gıda harcaması içindeki payı \%11.1 olarak hesaplanmıştır (Ertük ve ark. 2015).

Tüketicilerin \%44,01'i satın aldıkları ya da kendileri yaptıkları ekmeğin tamamını tükettiklerini belirtmişlerdir. Tüketiciler günlük tükettikleri ekmeğin \%9.17'sini israf etmektedirler. Türkiye'de 2012 yılı ekmek israfı oranının \%6 olduğu tespit edilmiştir (TMO, 2013). Araştırma sonucuna göre Kahramanmaraş ilindeki ekmek israf oranının Türkiye ortalamasının üzerinde olduğu görülmektedir. 2018 israf raporuna göre satın alınan ekmeğin günlük 71.4 gramını israf edilmektedir (Anonim, 2019e).

Çizelge 2. Ekmek tüketim bilgileri

\begin{tabular}{|c|c|c|c|c|c|c|c|c|}
\hline \multirow[b]{2}{*}{ Gelir (TL/ay) } & \multicolumn{2}{|c|}{$\begin{array}{c}\text { Tüketilen ekmek } \\
\text { miktarı } \\
\text { (adet/gün) }\end{array}$} & \multicolumn{2}{|c|}{$\begin{array}{c}\text { Ekmek harcaması } \\
\text { (TL/gün) }\end{array}$} & \multicolumn{2}{|c|}{$\begin{array}{c}\text { Gida harcaması } \\
\text { (TL/ay) }\end{array}$} & \multicolumn{2}{|c|}{$\begin{array}{c}\text { Aylık ekmek harcamasının } \\
\text { aylık gıda harcaması } \\
\text { içindeki payı (\%) }\end{array}$} \\
\hline & Ort. & Std. hata & Ort. & Std. hata & Ort. & Std. hata & Ort. & Std. hata \\
\hline 400-1999 & 2.86 & 0.171 & 2.75 & 0.164 & 305.57 & 13.689 & 27.00 & 0.021 \\
\hline 2000-3999 & 3.24 & 0.112 & 3.27 & 0.108 & 522.99 & 15.957 & 18.76 & 0.008 \\
\hline $4000-20000$ & 3.50 & 0.251 & 3.86 & 0.267 & 796.71 & 42.974 & 14.53 & 0.010 \\
\hline Genel & 3.18 & 0.091 & 3.24 & 0.092 & 512.62 & 15.096 & 18.96 & 0.008 \\
\hline $\begin{array}{l}\text { F değeri } \\
\text { ( } p \text { değeri) }\end{array}$ & \multicolumn{2}{|c|}{3.118} & \multicolumn{2}{|c|}{$\begin{array}{c}9.160 \\
(0.000)\end{array}$} & \multicolumn{2}{|c|}{$\begin{array}{l}93.592 \\
(0.000)\end{array}$} & \multicolumn{2}{|c|}{$\begin{array}{l}21.628 \\
(0.000)\end{array}$} \\
\hline
\end{tabular}

Tüketicilerin tercih ettikleri ekmek türlerini belirlemek amacıyla Çizelge 3 hazırlanmıştır. Tüketicilerin büyük bir oranının (\%68.75) somun ekmek, \%12.24'ünün pide, \%7.55'inin kepekli-çavdar ekmek, \%5.21'inin ise taş fırın ekmeği tercih ettikleri tespit edilmiştir (Çizelge 3). Araştırma sonuçları diğer çalışmalar ile karşılaştırıldığında Adana ilinde tüketicilerin \%89.6'sının somun ekmek (Gül ve ark., 2003), Konya ilinde tüketicilerin \%75'inin beyaz ekmek, \%52'sinin kepekli ekmek tercih ettikleri (Demir ve Kartal, 2012), Tokat ilinde ise tüketicilerin \%70.6'sının somun ekmek, \%22.1'inin köy ekmeği, \%11.4'ünün pide tercih ettikleri tespit edilmiştir (Bal ve ark., 2013).

Çizelge 3. Tercih edilen ekmek türleri

\begin{tabular}{lcc} 
& Birey sayısı & Oran (\%) \\
\hline Somun & 264 & 68.75 \\
Pide & 47 & 12.24 \\
Kepekli- çavdar ekmek & 29 & 7.55 \\
Taş fırın ekmeği & 20 & 5.21 \\
Tuzsuz ekmek & 19 & 4.95 \\
Diğer * & 5 & 1.30 \\
\hline Toplam & 384 & 100.00 \\
\hline
\end{tabular}

*Tost ekmeği, papatya ekmeği.

Tüketiciler artan ekmeklerini çeşitli şekillerde değerlendirmektedirler. Tüketicilerin \%29.43'ünün artan ekmekleri ısıtıp/kızartıp yeniden tükettikleri, \%23.96'sının farklı yemeklerde (köfte vb.) değerlendirdikleri belirlenmiştir (Çizelge 4). Tekirdağ ilinde ise tüketicilerin \%64'ü (Tanık, 2006), Van ilinde \%48.5'i (Koç, 2011) ve Adana ilinde ise \%80.4'ü (Gül ve ark. 2003) bayat ekmekleri farklı gıdalara dönüştürmektedirler.

Araştırmada ankete katılanların \%14.06'sının hayvanlara yem olarak verdikleri tespit edilmiştir (Çizelge 4). Tekirdağ ilinde tüketicilerin \%16.0'sı (Tanık, 2006), Van ilinde \%40.5'i (Koç, 2011) ve Isparta ilinde \%54.4'ü (Ertürk ve ark., 2015) bayatlayan ekmeği hayvan yemi olarak hayvanlara vermektedirler.Bayatlayan ekmeği, ekmek toplama kutularına atanların oranı ise \%6.77'dir (Çizelge 4). Türkiye genelinde yapılan araştırmada artan ekmeği başka bir öğünde tekrar kullananların oranı \%76.7, yiyecek olarak farklı yemeklerde değerlendirenlerin oranı \%47.5, hayvanlara verenlerin oranı ise \%15.5'tir (TMO, 2013).

Çizelge 4. Artan ekmeğin değerlendirilme şekli

\begin{tabular}{lcc}
\hline & $\begin{array}{c}\text { Birey } \\
\text { sayısı }\end{array}$ & $\begin{array}{c}\text { Oran } \\
\text { (\%) }\end{array}$ \\
\hline $\begin{array}{l}\text { Isıtıp/kızartıp yeniden tüketirim } \\
\text { Farklı yemeklerde (köfte vb.) }\end{array}$ & 113 & 29.43 \\
değerlendiririm & 92 & 23.96 \\
Hayvan yemi olarak veririm & 54 & 14.06 \\
Bayat tüketirim & 40 & 10.42 \\
Kapıcıya veririm & 30 & 7.81 \\
Belediye'nin bayat ekmek & 26 & 6.77 \\
toplama kutularına atarım & 15 & 3.91 \\
Ihtiyacı olana veririm & 14 & 3.65 \\
Diğer & 384 & 100.00 \\
\hline Toplam & & \\
\hline
\end{tabular}


Tüketicilerin \%55.99'unun ekmek israfı yaptığı (ekmeği çöpe atma eğiliminde olduğu), \%44.01'inin ise israf yapmadığı tespit edilmiştir. Ekmek israf etme durumu ile sosyo-demografik özellikler arasındaki ilişkiyi tespit etmek amacıyla verilere Ki-kare testi uygulanmıştır. Analizde ekmek israf etme durumu ile cinsiyet, medeni durum, eşin çalışması, oturulan binada kapıcının olması, yaş, eğitim, hanehalkı sayısı, gelir, çocuk sayısı, kilo problemi olma durumu ve ekmek satın alma sıklığı karşılaştırılmıştır. Araştırma sonucunda ekmek israf etme durumu ile eşin çalışması, kapıcının olması, hanehakı sayısı, gelir, kilo problemi olma durumu ve ekmek satın alma sıklığı arasında istatistiki açıdan anlamlı bir farkın olduğu tespit edilmiştir (Çizelge 5).

Ekmek israf etme durumu ile tüketicilerin oturdukları binada kapıcının olması arasında istatistiki açıdan anlamlı bir fark bulunmuştur $(p<0.01)$. Oturdukları binada kapıcısı olan tüketicilerin ekmek israf etme oranlarının daha yüksek olduğu tespit edilmiştir (Çizelge 5). Tüketicilerin taze ve sıcak ekmek tüketme isteği ile birlikte her an ekmek aldırabilecekleri birilerini bulabilmeleri, tüketicileri fazla ekmek almaya ve tazeliğini kaybeden ekmeği israf etmeye teşvik etmektedir.

Ekmek israf etme durumu ile hanehalkı birey sayısı arasında istatistiki açıdan anlamlı bir fark söz konusudur $(p<0.10)$. Ailesinde daha fazla kişi yaşayanların ekmek israf etme oranlarının daha yüksek olduğu gözlemlenmiştir. Hanehalkı birey sayısı arttıkça tüketilen ekmek sayısı artmakta ve bu durum ekmek israfına neden olmaktadır (Çizelge 5).

Ekmek israf etme durumu ile gelir arasında istatistiki açıdan anlamlı bir fark vardır $(p<0.05)$. Gelir arttıkça ekmek tüketim ve israf etme oranı artmaktadır. Araştırma bölgesinde geliri düşük olan tüketiciler genellikle evlerinde yufka ekmeği yapmaktadırlar. Sacda pişirilerek kurutulan bu ekmek çeşidi ıslatılarak intiyaca göre günlük taze olarak tüketilmektedir. Bu nedenle geliri düşük ailelerde ekmek tüketim ve israfı diğerlerine göre daha azdır. Geliri artan tüketiciler ise ekmeğin yerine ikame edilebilecekleri gıdaları (pilav, makarna gibi) sofralarında bulundurmakta ve alınan ekmekler tazeliğini yitirmekte ve israf edilmektedir (Çizelge 5).

Ekmek israf etme durumu ile ailede kilolu birey olma durumu arasında istatistiki açıdan anlamlı bir fark bulunmuştur $(p<0.10)$. Ailesinde kilolu birey bulunanların ekmek israf etme oranı, ailesinde kilolu birey olmayanlara göre daha yüksektir. Kilolu bireyler tarafından sıklıkla yapılan diyetler ekmek tüketiminin azalmasına katkı sağlarken, diyeti bozarım düşüncesi ile evde yedekte bekleyen ve artan ekmekler israf olarak nitelendirilebilir. Kilolu bireylerin başlamış oldukları diyetlerde öncelik ekmek tüketiminin azaltılması olduğundan, alınan ekmeklerin israfı söz konusu olabilir(Çizelge 5).

Ekmek israf etme durumu ile ekmek satın alım sıklığı arasında istatistiki açıdan anlamlı bir ilişki söz konusudur. Ekmek alım sıklığı arttıkça tüketicilerin ekmek israf etme oranları artmaktadır. Sık ekmek alan tüketicilerin daha çok israf ettikleri görülmektedir. Bunun en önemli nedeninin taze ekmek yemek isteği olduğu düşünülebilir (Çizelge 5). Suudi Arabistan'ın Riyadh şehrinde yapılan çalışmada tüketicilerin \%60.54'ünün her gün taze ekmek aldıkları ve bu durumun ekmek israfını artırdığı tespit edilmiştir (Aljobair, 2017).

\section{Sonuç ve Öneriler}

Bu çalışmada tüketicilerin ekmek israf etme durumları ve israfı etkileyen faktörlerin belirlenmesi amaçlanmaktadır. Bu amaçla yapılan Ki-kare testi sonuçlarına göre ekmek israf etme durumu ile eşin çalışması, oturdukları binada kapıcının olması, hanehalkı sayısı, gelir, kilo problemi olma durumu ve ekmek satın alma sıklığı arasında istatistiki açıdan anlamlı bir farkın olduğu tespit edilmiştir. Bu sonuçlar değerlendirildiğinde ekmeği sıklıkla satın alan ve taze olarak tüketen tüketicilerin ekmek israfını önlemek amacıyla ekmeğin gramajının azaltılması önerilmektedir. Geliri yüksek ve eşi çalışmayan tüketicilere, artan ekmekleri değerlendirmeleri yöntemlerini içeren seminerlerin verilmesi ekmek israfını azaltmaya katkı sağlayacaktır.

Araştırma sonucunda tüketicilerin önemli bir kısmının ekmeği israf ettiği görülmektedir. Ekmeğin tüketici geliri içinde payının düşük olması ve kolaylıkla ulaşılması ekmek israfının en önemli nedenlerindendir.

Ekmek israfının dolayısıyla ekonomik kayıpların en aza indirilmesi için kamu kurum ve kuruluşları, sivil toplum kuruluşları, belediyeler ve fırınlar tüketicilere ekmek saklama koşulları, bayat ekmeklerin değerlendirme yöntemleri hakkında bilgi veren seminerler düzenleyebilir, broşür ve liflet dağıtarak farkındalık oluşturabilirler. Politika yapıcılar; dilimli ekmek satışlarının özendirilmesi, bayatlayan ekmeği değerlendirme yöntemlerini içeren seminerlerin düzenlenmesi, bayat ekmek toplama kutularının yaygınlaştırılması gibi uygulamalarla ekmek israfının azalmasına katkı sağlayabilirler. Bunun yanı sıra yapılacak kamu spotları ve tüketici bilinçlendirme çalışmalara ile israfın azaltılmasına katkı sağlanabilir. 
Türk Tarım ve Doğa Bilimleri Dergisi 6(3): 432-439, 2019

Çizelge 5. İsraf etmede etkili faktörlerin ki-kare analizi (\%)

\begin{tabular}{|c|c|c|c|c|}
\hline & İsraf etmeyen & İsraf eden & Toplam & Ki-kare değeri ( $p$ değeri) \\
\hline \multicolumn{5}{|l|}{ Cinsiyet } \\
\hline Kadın & 40.12 & 59.88 & 100.00 & \multirow{3}{*}{$\begin{array}{c}1.718 \\
(0.190)\end{array}$} \\
\hline Erkek & 46.85 & 53.15 & 100.00 & \\
\hline Toplam & 44.01 & 55.99 & 100.00 & \\
\hline \multicolumn{5}{|l|}{ Medeni durum } \\
\hline Bekar & 44.68 & 55.32 & 100.00 & \multirow{3}{*}{$\begin{array}{c}0.194 \\
(0.660)\end{array}$} \\
\hline Evli & 42.16 & 57.84 & 100.00 & \\
\hline Toplam & 44.01 & 55.99 & 100.00 & \\
\hline \multicolumn{5}{|l|}{ Eşi çalışma durumu ** } \\
\hline Hayır & 51.61 & 48.39 & 100.00 & \multirow{3}{*}{$\begin{array}{c}6.436 \\
(0.011)\end{array}$} \\
\hline Evet & 36.64 & 63.36 & 100.00 & \\
\hline Toplam & 44.76 & 55.24 & 100.00 & \\
\hline \multicolumn{5}{|c|}{ Kapıcı olma durumu*** } \\
\hline Hayır & 49.59 & 50.41 & 100.00 & \multirow{3}{*}{$\begin{array}{c}8.456 \\
(0.004)\end{array}$} \\
\hline Evet & 34.29 & 65.71 & 100.00 & \\
\hline Toplam & 44.01 & 55.99 & 100.00 & \\
\hline \multicolumn{5}{|l|}{ Yaş } \\
\hline $19-29$ & 38.46 & 61.54 & 100.00 & \multirow{4}{*}{$\begin{array}{c}2.278 \\
(0.320)\end{array}$} \\
\hline $30-45$ & 47.57 & 52.43 & 100.00 & \\
\hline $46-70$ & 43.16 & 56.84 & 100.00 & \\
\hline Toplam & 44.01 & 55.99 & 100.00 & \\
\hline \multicolumn{5}{|l|}{ Eğitim } \\
\hline İlkokul ve altı & 51.72 & 48.28 & 100.00 & \multirow{4}{*}{$\begin{array}{c}1.352 \\
(0.717)\end{array}$} \\
\hline Ortaokul & 48.78 & 51.22 & 100.00 & \\
\hline Lise & 43.16 & 56.84 & 100.00 & \\
\hline Üniversite & 41.94 & 58.06 & 100.00 & \\
\hline \multicolumn{5}{|l|}{ Hanehalkı sayısı* } \\
\hline $1-2$ & 52.38 & 47.62 & 100.00 & \multirow{4}{*}{$\begin{array}{c}5.763 \\
(0.056)\end{array}$} \\
\hline $3-4$ & 45.00 & 55.00 & 100.00 & \\
\hline $5-10$ & 35.00 & 65.00 & 100.00 & \\
\hline Toplam & 44.01 & 55.99 & 100.00 & \\
\hline \multicolumn{5}{|l|}{ Gelir (TL)** } \\
\hline $400-1999$ & 53.51 & 46.49 & 100.00 & \multirow{4}{*}{$\begin{array}{c}6.082 \\
(0.048)\end{array}$} \\
\hline 2000-3999 & 40.72 & 59.28 & 100.00 & \\
\hline $4000-20000$ & 38.16 & 61.84 & 100.00 & \\
\hline Toplam & 44.01 & 55.99 & 100.00 & \\
\hline \multicolumn{5}{|l|}{ Çocuk sayısı } \\
\hline 0 & 49.52 & 50.48 & 100.00 & \multirow{4}{*}{$\begin{array}{c}3.680 \\
(0.159)\end{array}$} \\
\hline $1-2$ & 44.74 & 55.26 & 100.00 & \\
\hline $3-7$ & 35.96 & 64.04 & 100.00 & \\
\hline Toplam & 44.01 & 55.99 & 100.00 & \\
\hline \multicolumn{5}{|c|}{ Ailede kilo problemi olma durumu* } \\
\hline Hayır & 47.58 & 52.42 & 100.00 & \multirow{3}{*}{$\begin{array}{c}3.627 \\
(0.057)\end{array}$} \\
\hline Evet & 37.50 & 62.50 & 100.00 & \\
\hline Toplam & 44.01 & 55.99 & 100.00 & \\
\hline \multicolumn{5}{|c|}{ Ekmek satın alma sıklığı* } \\
\hline Her öğün & 36.05 & 63.95 & 100.00 & \\
\hline Günde iki kez & 39.47 & 60.53 & 100.00 & \\
\hline Günde 1 kez & 50.30 & 49.70 & 100.00 & $(0.094)$ \\
\hline Bir kaç günde bir & 52.63 & 47.37 & 100.00 & \\
\hline Toplam & 44.01 & 55.99 & 100.00 & \\
\hline
\end{tabular}




\section{Kaynaklar}

Açan, B. 2007. Kolayda mallarda müşteri profili ve tüketim tercihleri: İstanbul halk ekmek müşterilerine yönelik bir araştırma. Atatürk Üniversitesi iktisadi ve İdari Bilimler Dergisi, 21(2): 261-280.

Akbay, C. 2005. Kahramanmaraş'ta hanehalklarının gIda tüketim talebi ekonometrik analizi. KSÜ Fen ve Mühendislik Dergisi, 8(1): 114-121.

Akbay, C., Bilgiç. A., Miran, B. 2008. Türkiye'de önemli gıda ürünlerinin talep esneklikleri. Tarım Ekonomisi Dergisi, 14 (2): 55-65.

Aljobair, M.O. 2017. Assessment of the bread consumption habits among the people of Riyadh. Saudi Arabia. Pak. J. Nutr., 16: 293298.

Anonim, 2019a. Beslenme Nedir? https://www.ilkokul.nds.k12.tr/IMG/pdf/ BESLENME_NEDIR.pdf (Erişim tarihi: 24.02.2019).

Anonim, 2019b. Geçmişten Günümüze Buğday. http://apelasyon.com/Yazi/410-gecmistengunumuze-bugday (Erişim tarihi: 24.02.2019).

Anonim, 2019c. Ekmeğin Tarihçesi. https://mauri.com.tr/ekmegin-tarihcesi/.

(Erişim tarihi: 24.02.2019)

Anonim, 2019d. Türkiye'de Ekmek İsrafı Araştırması https://www.gidahatti.com/tu erkiye-deekmek-israf-arast-rmas-39038/(Erişim tarihi: 26.02.2019).

Anonim, 2019e. Türkiye İsraf Raporu http://tuketici.ticaret.gov.tr/data/5c6ea aeaddee7d8e04e8c73d/31-01 2019\%20ISRAF\%20TEKRAR.pdf (Erişim tarihi: 20.06.2019).

Aydın, F., Yıldız Ş. 2011. Sivas ilinde ekmek tüketim alışkanlıkları ve tüketici dinamiklerinin belirlenmesi. Atatürk Üniv. Ziraat Fak. Derg., 42(2): 165-180.

Bal, Z. E., Sayılı M., Gözener M. 2013. Tokat ili Merkez ilcçede Ailelerin Ekmek Tüketimleri Üzerine Bir Araştırma. JAFAG 30(1): 61-69.

Boyacıoğlu, O. 2019. Ekmek Tüketimi ve Tüketici Beklentileri. https://www.okan.edu. tr/uploads/announcement/prof-dr-m-hikmetboyacioglu-ekmek-israfini onleyelim/EkmekTu ketimi-ve-Tuketici-Beklentileri-PanelMayis-2013.pdf.

Capone R., Bilali H.E., Debs P., Bottalico F., Cardone G., Berjan S., Elmenofi G.A.G., Abouabdillah A., Charbel L., Arous S.A., Sassi K. 2016. Bread waste in Mediterranean Arab countries. 5th International Symposium on Agricultural
Sciences, February 29 - March 3, Banja Luka, Bosnia and Herzegovina Abstract Book, p.220.

Cop, R., Doğan, H. 2009. Ekmek üretiminde yeni ürün geliştirme ve tüketici tutumlarıla ilgili bir uygulama. Abant İzzet Baysal Üniversitesi Sosyal Bilimler Enstitüsü Dergisi, 1(18): 12-26.

Çağrı, H. 2016. İsraf Sorunu: Türkiye'de Ekmek İsrafı Sorunu ve Türkiye Ekonomisi Üzerindeki Etkileri. Nevşehir Hacı Bektaş Veli Üniversitesi Sosyal Bilimler Enstitüsü Iktisat Anabilim Dalı, Yayınlanmamış Yüksek Lisans Tezi, Nevşehir.

Demir, M.K., Kartal, H. 2012. Konya ilinde farklı ekmek çeşitlerini tüketen bireyler üzerinde yapılan bir anket çalışması. Gıda teknolojileri elektronik dergisi, 7(3): 59-64.

Demirtaş, B., Kaya, A., Sağıstan, E. 2018. Consumers' bread consumption habits and waste status: Hatay/Turkey Example, Turkish Journal of Agriculture - Food Science and Technology, 6(11): 1653-1661.

Dölekoğlu, C.Ö., Giray, H.F., Şahin, A. 2014. Mutfaktan Çöpe Ekmek: Tüketim ve Değerlendirme, Akademik Bakış Dergisi, iktisat ve Girişimcilik Üniversitesi, Türk Dünyası Kırgız-Türk Sosyal Bilimler Enstitüsü,, ISSN:1694-528X Celalabat- Kırgızistan Sayı:44.

Ekmekçi Bal, Z., Sayılı, M. ve Gözener, M. 2013. Tokat ili merkez ilçede ailelerin ekmek tüketimleri üzerine bir araştırma. Gaziosmanpaşa Üniversitesi Ziraat Fakültesi Dergisi, 30(1): 6169.

Ertürk, A., Arslantaş, N., Sarıca, D. ve Demircan, V. 2015. Isparta ili kentsel alanda ailelerin ekmek tüketimi ve israfı. Akademik Gıda, 13(4): 291-298.

Gül, A., Işık, H., Bal, T., Özer, S. 2003. Bread Consumption and waste of households in urban area of Adana province. Electronic Journal of Polish Agricultural Universities, Food Science and Technology, 6(2): 10-16.

Koç, B. 2011. Ekmek Tüketiminde Tüketici Tercihleri: Van Illi Örneği. Tarımsal Ekonomi ve Politika Geliştirme Enstitüsü Yayını, TEPGE Yayın No: 196, Ankara.

Mohammmadi, I.M., 2006. Factors influencing wheat, flour, and bread waste in Iran. Journal of New Seeds, 8(4): 67-78.

Newbold, P. 1995. Statistics for Business and Economics, Prentice-Hall International, New Jersey, 867pp.

Tanık, O. 2006. Ekmek Üretiminde Kalite Uygulamaları ve Müşteri Memnuniyet Dinamiklerinin Belirlenmesi. Trakya 
Üniversitesi Fen Bilimleri Enstitüsü (Yayımlanmamış Yüksek Lisans Tezi) Tekirdağ.

Taşcı, R., Karabak, S., Bolat, M., Acar, O., Şanal, T., Pehlivan, A., Külen, S., Güneş, E., Albayrak, M. 2017. Ankara ilinde ekmekte tüketici tercihleri. Tarla Bitkileri Merkez Araştırma Enstitüsü Dergisi, 26(1): 75-85.

TMO, 2013. Türkiye'de Ekmek İsrafı Raporu. http://www.tmo.gov.tr/Upload/Document /Kampanya/ArastirmaKitabi.pdf (Erişim tarihi: 24.02.2019). 